\title{
Edge Effects on Successional Dynamics of Forest Fragments in the Brazilian Cerrado
}

\author{
Firmino Cardoso Pereira ${ }^{1}$ (]) \\ Frederico Augusto Guimarães Guilherme ${ }^{2}$ \\ Beatriz Schwantes Marimon ${ }^{1}$ (I)
}

\begin{abstract}
Comparative studies of tree dynamics can be useful for the conservation of forest fragments in the Cerrado. We tested if the successional dynamics in fragments of semideciduous forest (SF) and cerradão (CE) are influenced by edge effects (EE). Two surveys were carried out with plots allocation in both physiognomies, from the edge towards the interior of the fragments. All trees with diameter at breast height $\geq 5 \mathrm{~cm}$ were measured, identified and classified (ecological groups). Both physiognomies showed high recruitment and mortality rates when compared with other forests in Cerrado. We found an EE on tree density (SF), and on mortality, total basal area and basal area of dead (CE), although do not so notorious on a short-term scale. Probably because EE did not influence the ecological groups and canopy cover. Our results suggest that the forest fragmentation can act as a disturbance agent, causing changes in the tree dynamics of the Cerrado forests.
\end{abstract}

Keywords: cerradão, semideciduous forest, tree monitoring, forest fragmentation, canopy cover.

\section{INTRODUCTION AND OBJECTIVES}

Deforestation in continuous natural ecosystems results in fragmentation and consequent edge zones, which afford the so-called edge effects (Murcia, 1995). This promotes biotic and abiotic changes resulting from the abrupt transition between the fragment and adjacent matrix (Laurance \& Vasconcelos, 2009), e.g. cattle pastures, monocultures and highways. Such changes can be abiotic, affecting microclimate conditions, incidence of light and wind (Camargo \& Kapos, 1995; Didham \& Lawton, 1999). Or biotic, modifying over time, the plant species abundance and composition, interactions between organisms, structure and dynamics of natural ecosystems (Harper et al., 2005; Magrach et al., 2014; Terra et al., 2018).

Edge effects have been widely studied in tropical forests, especially the Amazon (Nascimento \& Laurance, 2006; Laurance \& Vasconcelos, 2009). For savannas, these studies have deserved attention in recent years. In African savannas, borders can alter plant and animal distributions (Porensky, 2011), vegetation composition and structure (Hennenberg, 2005; Smit \& Asner, 2012). Specifically, in Brazilian Cerrado, the most significant edge influence threatening the conservation of Cerrado vegetation seems to be the exotic grasses invasion (Dodonov et al., 2013; Mendonça et al., 2015). Other studies have observed the edge effects in plant litter (Dodonov et al., 2016), on native vegetation phenology (Ishino et al., 2012; Vogado et al., 2016), composition and structure (Lima-Ribeiro, 2008), plants with different dispersal mechanisms (Jardim \& Batalha 2009), and interactions between animal-plants (Christianini \& Oliveira, 2013). However, most of these studies were carried out on typically savanna physiognomies.

Some few studies relating the edge influence on forests ecosystems in Brazilian Cerrado have been carried out by Sampaio \& Scariot (2011) and Arruda \& Eisenlohr (2016), in seasonal dry forests. Like these, semideciduous forests and cerradões (woody savanna) occur in well-drained and interfluvial regions typical of the biome. Both have horizontal and vertical structure relatively similar (Guilherme \& Nakajima, 2007), although the flora of the cerradões resembles a more xeromorphic condition, typical of open savannas, with both savanna and forest species (Ribeiro \& Walter, 2008). Therefore, the Cerrado is quite heterogeneous, alternating physiognomies over short distances, which sometimes increases the difficulty of understanding the anthropogenic consequences in natural

${ }^{1}$ Universidade do Estado de Mato Grosso (UNEMAT), Campus Nova Xavantina, Nova Xavantina, MT, Brasil

${ }^{2}$ Universidade Federal de Jataí (UFJ), Unidade Acadêmica de Ciências Biológicas, Jataí, GO, Brasil 
ecosystems. This is worsened by increased fragmentation in Central Plateau of Brazil, threatening the ecosystems functioning and biodiversity (Guilherme et al., 2016).

Forests dynamics are determined by mortality, recruitment and growth of individuals, and the contact between the edge and surrounding matrix (e.g., pastures) can change species abundance and most dynamic parameters (Oliveira-Filho et al., 2007).The change of these parameters, due to forest fragmentation, consequently modifies the successional dynamics of trees (Laurance et al., 2006) and canopy cover (Matlack, 1993; Harper et al., 2004). Previous studies about forest ecosystems in the Cerrado Biome have also shown that the anthropogenic threats could influence successional dynamics (Silva \& Araújo, 2009; Peixoto et al., 2012; Marimon et al., 2014; Reis et al., 2015), but their results are still inconclusive.

Although the consequences of fragmentation between border-interior of this ecosystems are expected to be different between them (Mendonça et al., 2015), edge effects studies comparing the tree community dynamics of seasonal forests and cerradão are unknown. However, the evaluation of edge influence in these different physiognomies in the same region may help to understand the fragmentation effects in Cerrado. So, our study aimed to assess edge influence on the dynamics of semideciduous forest and cerradão fragments. Specifically, we tested how the dynamics of the tree community, successional stages, and canopy cover of fragments are influenced by edge effects.

\section{MATERIALS AND METHODS}

We conducted this study in seven forest fragments along the Indaiá River Basin, Cassilândia, Mato Grosso do Sul (see the data of field in supplementary material 1). Five represent semideciduous forest (SF) and two cerradão (CE). The climate of the region is Köppen's Aw, with two welldefined periods, one dry and cold (April to September) and the other wet and hot (October to March), as is characteristic in the Midwest region of Brazil. The rainfall levels show an annual average of about $1500 \mathrm{~mm}$, with maximum rainfall in December and January, and average annual temperature between $23-24^{\circ} \mathrm{C}$ (Wachholz et al., 2020). Oxisols and Argisols are the predominant soil type in the region, and the fragments do not show noticeable differences in soil texture.

The studied region is anthropized and fragments of SF predominate, which explains a greater number of samples than in the CE (Table 1). None of the fragments show traces of recent fire and are surrounded predominantly by pastures, except a small stretch of two SF fragments connected with riparian forests. Although all plots were sampled on the side facing the pasture matrix. The number of plots was variable for each fragment, since we tried to standardize the allocation of pairs of plots (edge-interior) according to the conservation status and physical aspects, such as same edaphic conditions. Therefore, we adopt the assumptions that the environmental conditions are similar for both physiognomies.

The first vegetation survey was carried out between December 2010 and October 2011. We systematically established $72-200 \mathrm{~m}^{2}(10 \times 20 \mathrm{~m})$ plots, 48 and 24 in SF and $\mathrm{CE}$, respectively, always covering edge (edge vegetation start) and interior of the fragments, at an approximately distance of $100 \mathrm{~m}$ for each pair of plots (edge-interior), totalizing 1.44 ha. In each plot, we labeled, recorded, and identified all trees with diameter at breast height $\left(\mathrm{DBH}_{1.30 \mathrm{~m}}\right) \geq 5 \mathrm{~cm}$.

Table 1. Fragment size, number of plots and geographic coordinates of semideciduous forest (SF) and cerradão (CE) fragments in the Indaiá River Basin in Cassilândia, Mato Grosso do Sul, Brazil.

\begin{tabular}{|c|c|c|c|c|c|}
\hline \multirow{2}{*}{ Fragment } & \multirow{2}{*}{ Area (ha) } & \multicolumn{3}{|c|}{ Number of plots $\left(200 \mathrm{~m}^{2}\right)$} & \multirow{2}{*}{ Geographic coordinates } \\
\hline & & Edge & Interior & Total & \\
\hline SF1 & 65 & 5 & 5 & 10 & $19^{\circ} 10^{\prime} 41.08^{\prime \prime} \mathrm{S} / 52^{\circ} 19^{\prime} 56.75^{\prime \prime} \mathrm{W}$ \\
\hline SF2 & 20 & 4 & 4 & 8 & $19^{\circ} 9^{\prime} 32.55^{\prime \prime} \mathrm{S} / 52^{\circ} 23^{\prime} 9.37^{\prime \prime} \mathrm{W}$ \\
\hline SF3 & 24 & 3 & 3 & 6 & $19^{\circ} 16^{\prime} 24.59^{\prime \prime} \mathrm{S} / 52^{\circ} 24^{\prime} 38.22^{\prime \prime} \mathrm{W}$ \\
\hline $\mathrm{SF} 4^{*}$ & 78 & 6 & 6 & 12 & $19^{\circ} 13^{\prime} 36.86^{\prime \prime} \mathrm{S} / 52^{\circ} 22^{\prime} 3.01^{\prime \prime} \mathrm{W}$ \\
\hline $\mathrm{SF}^{*}$ & 76 & 6 & 6 & 12 & $19^{\circ} 8^{\prime} 29.41^{\prime \prime S} / 52^{\circ} 24^{\prime} 16.20^{\prime \prime} \mathrm{W}$ \\
\hline CE1 & 242 & 6 & 6 & 12 & $19^{\circ} 13^{\prime} 27.95^{\prime \prime S} / 52^{\circ} 27^{\prime} 9.11^{\prime \prime} \mathrm{W}$ \\
\hline CE2 & 33 & 6 & 6 & 12 & $19^{\circ} 6^{\prime} 51.26^{\prime \prime} \mathrm{S} / 52^{\circ} 16^{\prime} 25.93^{\prime \prime} \mathrm{W}$ \\
\hline
\end{tabular}

* Connected with riparian forests.

In July 2014, we performed the second survey in all plots when we measured the surviving individuals, and registering recruited trees, which reached the minimum inclusion $\mathrm{DBH}$, and dead trees as well. Specimens with doubtful identification were collected and deposited in the Herbarium Jataiense (HJ), Federal University of Jataí, Goiás State. Nomenclature for families followed APG IV (2016) and for species followed the "Flora Species List of Brazil' (http://floradobrasil.jbrj.gov.br/2020). 
In order to compare the vegetation response to successional groups between edge and interior of fragments, we classified the species according to the demand for light, in three categories: pioneer $(\mathrm{P})$, light demanding (LD), and shade tolerant (SD) (sensu Swaine \& Whitmore, 1988). We measured canopy cover (\%) in each plot in the dry (April to September) and rainy periods (October to March), using a concave spherical densiometer. Measurements were taken in four cardinal directions in the center of each plot at $1.3 \mathrm{~m}$ above the ground, to determine an average value per plot.

We calculated the average annual rates of mortality and recruitment for the edge and interior, considering the number of individuals (NI) and basal area (BA), followed by the correction factor for bias related to the interval variation between censuses (Lewis et al., 2004). We also calculated stability time (number of years needed to stabilize the NI or BA), turnover rate (years to reestablish the initial NI or BA), net change rate (annual percentage change in NI or BA), and average annual rates of basal area gain and loss (Sheil et al., 2000). The formulas of the dynamics parameters are in the supplementary material 2.

Using the plots with sample, we compared canopy cover, successional group, community parameters, and number and basal area of living, recruit, and dead individuals between edge and interior using a Student $t$-test for each physiognomy. When residuals were not normal with the Shapiro-Wilk test, we logtransformed the data or used a Mann-Whitney tests (U). We tested the homogeneity of variance using a Levene test, and we ran a separate variances $t$-test for data with heterogeneous variances (Zar, 2010). One plot at the edge of a CE fragment was damaged and excluded from further analysis.

\section{RESULTS}

\subsection{Community dynamics}

SF showed a small change $(+0.7 \%)$ in density between 2011 and 2014, recruitment rate was higher than mortality rate, while net change of the individuals increased slightly (Table 2). The NI change was close to zero and turnover was $24.51 \%$ year $^{-1}$. BA decreased (3.4\%), due to the death of individuals, and the net change was small. Furthermore, BA in the SF was unstable with slow turnover.

In the $\mathrm{CE}$, the NI also increased $(+1.4 \%)$ between 2011 and 2014, and the recruitment was higher than the mortality rate, like in the SF. Thus, net change indicated gain of individuals and growth in BA (5.4\%). This gain was mostly due to survivors, since the BA of dead individuals was greater than that of recruits. Therefore, the loss of BA surpassed its gain. Thus, its net change was positive, although the $\mathrm{BA}$ of the $\mathrm{CE}$ was unstable and turnover slow, but faster than in the SF.
Table 2. Tree community dynamics parameters of semideciduous forest (SF) and cerradão (CE) fragments in Cassilândia, Mato Grosso do Sul, Brazil.

\begin{tabular}{|c|c|c|c|}
\hline Parameters & SF & CE & Total \\
\hline \multicolumn{4}{|l|}{ Number of individuals } \\
\hline Initial (2011) & 1107 & 934 & 2041 \\
\hline Final (2014) & 1115 & 947 & 2062 \\
\hline Survivors & 1015 & 858 & 1873 \\
\hline Deads & 92 & 76 & 168 \\
\hline Recruits & 100 & 89 & 189 \\
\hline Mortality rate $\left(\%\right.$ year $\left.{ }^{-1}\right)$ & 3.05 & 3.95 & 2.62 \\
\hline Recruitment rate (\% year $\left.{ }^{-1}\right)$ & 3.64 & 5.07 & 3.24 \\
\hline Stability time $\left(\%\right.$ year $\left.{ }^{-1}\right)$ & -0.07 & 1.24 & 0.86 \\
\hline Turnover ( $\%$ year $\left.^{-1}\right)$ & 24.51 & 17.74 & 28.46 \\
\hline Net change ( $\%$ year $\left.^{-1}\right)$ & 0.23 & 0.38 & 0.28 \\
\hline \multicolumn{4}{|l|}{ Basal area $\left(\mathrm{m}^{2}\right)$} \\
\hline Initial (2011) & 26.26 & 10.91 & 37.18 \\
\hline Final (2014) & 25.36 & 11.53 & 36.90 \\
\hline Survivors & 25.07 & 11.24 & 36.31 \\
\hline Deads & 3.09 & 0.76 & 3.86 \\
\hline Recruits & 0.29 & 0.29 & 0.58 \\
\hline Rate of loss $\left(\%\right.$ year $\left.^{-1}\right)$ & 4.65 & 4.39 & 3.63 \\
\hline Rate of gain $\left(\%\right.$ year $\left.^{-1}\right)$ & 3.60 & 4.71 & 3.49 \\
\hline Stability time (\% year $\left.{ }^{-1}\right)$ & -174.44 & -37.06 & 21.26 \\
\hline Turnover $\left(\%\right.$ year $\left.^{-1}\right)$ & 104.17 & 39.90 & 12.00 \\
\hline Net change $\left(\%\right.$ year $\left.{ }^{-1}\right)$ & -1.13 & 1.56 & -0.21 \\
\hline
\end{tabular}

\subsection{Edge and interior dynamics}

The NI at the edge of SF was the same in both inventories, mainly due to the similarity in number of dying and recruiting individuals, with an increase of eight individuals inside the fragments (Table 3). Tree density at the edge of SF was higher than in the interior, but both did not differ in NI dead and recruits.

The average annual recruitment rate (individual-basis) was slightly higher than the mortality rate at the edge of the SF, but not there to net change (Table 3). Conversely, recruitment rate at the interior was $33 \%$ higher than mortality, but the net change was less than $1 \%$. The edge and interior did not differ in mortality and recruitment rates, turnover, and net change for NI.

In SF, for the second inventory (2014), the BA of the edge and the interior were lower than in 2011, since the BA of recruits and survivors growth did not compensate the dead individuals (Table 3). However, there were no differences between edge and interior in its final, recruits, and dead individuals $\mathrm{BA}$. The loss of $\mathrm{BA}$ at the edge and interior 
exceeded the gain, and net change was negative in both environments. BA loss and gain, net change, and turnover of SF did not differ between the edge and interior.

In the $C E$ there was an increase of four and nine individuals between the surveys at the edge and interior, respectively (Table 3). The density and number of recruits did not differ, but the edge plots showed, on average, almost two dead individuals more than the interior. Recruitment rates exceeded mortality, and net change was positive in both environments, and turnover was higher in the interior than the edge. There was a difference in mortality rate for the edge and interior, but not for recruitment, net change, and turnover.

The BA of dead individuals at the edge of $\mathrm{CE}$ was significatively higher than the interior, whereas the BA of recruits did not differ (Table 3). The final $\mathrm{BA}$ at the edge of $C E$ was on average $0.12 \mathrm{~m}^{2}$ larger than in the interior. The BA loss rate at the edge was higher than the gain, while the opposite occurred in the interior. The loss, gain, net change, and turnover did not differ between the edge and interior of the CE.

Table 3. Tree community dynamics parameters between the edge (E) and interior (I) in semideciduous forest (SF) and cerradão (CE) fragments in Cassilândia, Mato Grosso do Sul, Brazil. In= initial; $\mathrm{F}=$ final; $\mathrm{r}=$ recruits; $\mathrm{d}=$ dead; average annual rates of mortality (M) and recruitment (R) $\left(\% \mathrm{yr}^{-1}\right) ; \mathrm{NC}=$ net change $\left(\% \mathrm{yr}^{-1}\right)$; $\mathrm{T}=$ turnover $\left(\% \mathrm{yr}^{-1}\right)$; average annual rates of loss $(\mathrm{L})$ and gain $(\mathrm{G})$ in basal area $\left(\% \mathrm{yr}^{-1}\right)$.

\begin{tabular}{|c|c|c|c|c|c|c|}
\hline & \multicolumn{3}{|r|}{ SF } & \multicolumn{3}{|r|}{$\mathrm{CE}$} \\
\hline & $\mathbf{E}$ & I & Comparison & $\mathbf{E}$ & $\mathbf{I}$ & Comparison \\
\hline \multicolumn{7}{|c|}{ Number of individuals } \\
\hline In & 623 & 484 & & 463 & 471 & \\
\hline $\mathbf{F}$ & 623 & 492 & $\begin{array}{c}t=2.74 ; \mathrm{df}=46 \\
\mathrm{p}=\mathbf{0 . 0 1}\end{array}$ & 467 & 480 & $\begin{array}{c}t=0.55 ; \mathrm{df}=21 ; \\
p=0.58\end{array}$ \\
\hline $\mathbf{r}$ & 55 & 45 & $\mathrm{U}=330.5 ; p=0.37$ & 51 & 38 & $\begin{array}{c}t_{(\log )}=1.74 \\
\mathrm{df}=21 ; p=0.09\end{array}$ \\
\hline d & 55 & 37 & $\mathrm{U}=354 ; p=0.16$ & 47 & 29 & $\begin{array}{c}t=2.41 ; \mathrm{df}=21 ; \\
p=0.02\end{array}$ \\
\hline $\mathbf{M}$ & 3.24 & 2.80 & $\mathrm{U}=308.5 ; p=0.67$ & 4.95 & 2.97 & $\begin{array}{c}t_{(\log )}=2.18 \\
\mathrm{df}=21 ; \boldsymbol{p}=\mathbf{0 . 0 4}\end{array}$ \\
\hline $\mathbf{R}$ & 3.57 & 3.72 & $\mathrm{U}=310 ; p=0.65$ & 6.02 & 4.18 & $\begin{array}{c}t_{(\log )}=1.86 ; \\
\mathrm{df}=21 ; p=0.07\end{array}$ \\
\hline NC & 0.00 & 0.53 & $\mathrm{U}=269 ; p=0.70$ & 0.24 & 0.52 & $\begin{array}{c}t=-0.67 ; \mathrm{df}=21 ; \\
p=0.50\end{array}$ \\
\hline $\mathbf{T}$ & 24.04 & 25.29 & $\begin{array}{c}t_{(\log )}=-0.36 \\
\mathrm{df}=30 ; p=0.72\end{array}$ & 14.7 & 22.31 & $\begin{array}{c}t_{(\log )}=-1.35 \\
\mathrm{df}=20 ; p=0.19\end{array}$ \\
\hline \multicolumn{7}{|c|}{ Basal area $\left(\mathbf{m}^{2}\right)$} \\
\hline In & 13.79 & 12.47 & & 5.98 & 4.93 & \\
\hline $\mathbf{F}$ & 13.13 & 12.24 & $\begin{array}{c}t_{(\log )}=1.25 ; \\
\mathrm{df}=38.31 ; p=0.21\end{array}$ & 6.23 & 5.30 & $\begin{array}{c}t=2.94 ; \mathrm{df}=21 ; \\
\boldsymbol{p}=\mathbf{0 . 0 0 7}\end{array}$ \\
\hline $\mathbf{r}$ & 0.17 & 0.11 & $\mathrm{U}=348.5 ; p=0.21$ & 0.16 & 0.12 & $\begin{array}{c}t=0.97 ; \mathrm{df}=22 ; \\
p=0.34\end{array}$ \\
\hline
\end{tabular}

Table 3. Continued...

\begin{tabular}{|c|c|c|c|c|c|c|}
\hline & \multicolumn{3}{|c|}{ SF } & \multicolumn{3}{|r|}{ CE } \\
\hline & $\mathbf{E}$ & I & Comparison & $\mathbf{E}$ & I & Comparison \\
\hline \multicolumn{7}{|c|}{ Number of individuals } \\
\hline d & 1.69 & 1.39 & $\begin{array}{c}\mathrm{U}=280.5 \\
p=0.88\end{array}$ & 0.56 & 0.20 & $\begin{array}{c}t=2.77 \\
\mathrm{df}=11.22 \\
p=\mathbf{0 . 0 1}\end{array}$ \\
\hline $\mathbf{L}$ & 5.02 & 4.25 & $\begin{array}{c}t_{(\log )}=-0.58 ; \\
\mathrm{df}=46 ; p=0.55\end{array}$ & 5.75 & 2.76 & $\begin{array}{c}t_{(\log )}=1.77 ; \\
\mathrm{df}=21 ; p=0.08\end{array}$ \\
\hline G & 3.51 & 3.69 & $\begin{array}{c}t_{(\log )}=-0.68 ; \\
\mathrm{df}=46 ; p=0.49\end{array}$ & 5.24 & 4.10 & $\begin{array}{c}t=-0.16 ; \mathrm{df}=21 ; \\
p=0.86\end{array}$ \\
\hline NC & -1.61 & -0.61 & $\mathrm{U}=263 ; p=0.61$ & 1.15 & 2.05 & $\begin{array}{c}t=-1.10 ; \mathrm{df}=21 ; \\
p=0.28\end{array}$ \\
\hline $\mathbf{T}$ & 93.10 & 120.12 & $\begin{array}{c}t_{(\log )}=-0.21 ; \\
\mathrm{df}=30 ; p=0.83\end{array}$ & 35.77 & 49.35 & $\begin{array}{c}t_{(\log )}=-1.55 ; \\
\mathrm{df}=20 ; p=0.13\end{array}$ \\
\hline
\end{tabular}

\subsection{Successional stages and canopy cover}

Both forests types had higher abundance of light demanding species, followed by pioneer species. However, the abundance and species richness of successional groups did not differ between edge and interior (Table 4).

Table 4. Abundance and tree species richness in each successional stage in the edge (E) and interior (I) of semideciduous forest (SF) and cerradão (CE) fragments in Cassilândia, Mato Grosso do Sul, Brazil. $\mathrm{LD}=$ light demanding; $\mathrm{P}=$ pioneers; $\mathrm{SD}=$ shade tolerant. The table with species list and successional groups is provided in the supplementary material 3.

\begin{tabular}{|c|c|c|c|c|c|c|}
\hline & & & SF & & & $\mathrm{CE}$ \\
\hline & $\mathbf{E}$ & I & Comparison & E & I & Comparison \\
\hline & bunda & nce & & & & \\
\hline LD & 13.50 & 10.00 & $\begin{array}{c}t=1.97 ; \mathrm{df}=46 ; \\
p=0.054\end{array}$ & 23.54 & 22.66 & $\begin{array}{c}t=0.25 ; \mathrm{df}=21 \\
p=0.80\end{array}$ \\
\hline $\mathrm{P}$ & 6.29 & 4.29 & $\begin{array}{c}\mathrm{t}=1.97 ; \mathrm{df}=46 ; \\
p=0.054\end{array}$ & 14.81 & 14.50 & $\begin{array}{c}t_{(\log )}=-0.03 \\
\mathrm{df}=21 ; p=0.97\end{array}$ \\
\hline SD & 4.12 & 4.45 & $\begin{array}{c}\mathrm{U}=300.5 \\
p=0.80\end{array}$ & 2.00 & 2.83 & $\begin{array}{c}t=-0.98 ; \mathrm{df}=21 ; \\
p=0.33\end{array}$ \\
\hline & Sp & ecies $\mathbf{r i}$ & hness & & & \\
\hline LD & 6.25 & 4.83 & $\begin{array}{c}t=1.97 ; \mathrm{df}=46 ; \\
p=0.053\end{array}$ & 11.09 & 11.16 & $\begin{array}{c}t=0.24 ; \mathrm{df}=21 \\
\mathrm{p}=0.81\end{array}$ \\
\hline $\mathrm{P}$ & 3.87 & 3.16 & $\begin{array}{c}t=1.56 ; \mathrm{df}=46 ; \\
p=0.12\end{array}$ & 6.33 & 6.66 & $\mathrm{U}=75 \cdot p=0.89$ \\
\hline SD & 1.75 & 1.88 & $\begin{array}{c}\mathrm{U}=266.5 \\
p=0.65\end{array}$ & 1.33 & 1.22 & $\mathrm{U}=51 . \mathrm{p}=0.55$ \\
\hline
\end{tabular}

The canopy cover of both physiognomies did not differ between the edge and interior, regardless of the period (Table 5). However, canopy cover varied throughout the year considering both forests, being significantly higher in the rainy than in the dry period. 
Table 5. Canopy cover (\%) in the edge (E) and interior (I) for each and between periods in semideciduous forest (SF) and cerradão (CE) fragments in Cassilândia, Mato Grosso do Sul, Brazil.

\begin{tabular}{|c|c|c|c|c|c|c|}
\hline \multirow{2}{*}{ Periods } & \multicolumn{3}{|c|}{ SF } & \multicolumn{3}{|r|}{$\mathrm{CE}$} \\
\hline & $\mathbf{E}$ & I & Comparison & $\bar{E}$ & I & Comparison \\
\hline Rainy & 83.03 & 85.58 & $\mathrm{U}=259 ; p=0.55$ & 87.63 & 86.11 & $t=0.87 ; \mathrm{df}=21 ; p=0.39$ \\
\hline Dry & 81.82 & 82.55 & $t=-0.40 ; \mathrm{df}=46 ; p=0.68$ & 78.51 & 79.52 & $t=0.87 ; \mathrm{df}=21 ; p=0.39$ \\
\hline Rainy & \multicolumn{2}{|c|}{84.30} & $\mathrm{U}=279 ; \mathrm{p}=\mathbf{0 . 0 0 4}$ & \multicolumn{2}{|c|}{86.84} & $t=-6.11 ; \mathrm{df}=22 ; \mathrm{p}=\mathbf{0 . 0 0 1}$ \\
\hline Dry & \multicolumn{2}{|c|}{82.19} & $0=2 / 9 ; p=0.004$ & \multicolumn{2}{|c|}{79.04} & $l=-0.11 ; \mathrm{d1}=22 ; \mathrm{p}=\mathbf{0 . 0 0 1}$ \\
\hline
\end{tabular}

\section{DISCUSSION}

\subsection{Community dynamics}

The increased density and decreased BA in the SF contrasted with the increased density and BA in the $\mathrm{CE}$ in the second survey (2014), but there was little variation to the net change between physiognomies. This suggest that the physical aspects, such as soil and climate, and the fragmented nature of these forests, offer the same vegetation dynamics responses. The mortality and recruitment rates of the studied fragments are high compared to undisturbed and non-fragmented Amazon forests (Lewis et al., 2004; Phillips et al., 2004), and other forest ecosystems of the Cerrado, such as gallery forests (Miguel et al., 2011; Oliveira et al., 2014), semideciduous forest (Higuchi et al., 2008; Marimon et al., 2014; Oliveira et al., 2014) and cerradões (Franczak et al., 2011; Reis et al., 2015). Thus, the rates reported in this study are among the highest even compared to fragmented forests (Oliveira-Filho et al., 1997; Oliveira-Filho et al., 2007; Higuchi et al., 2008).

Tree community dynamics usually change after natural (Guilherme et al., 2004; Appolinário et al., 2005; Guimarães et al., 2008) or man-made disturbances (OliveiraFilho et al., 1997; Oliveira-Filho et al., 2007; Peixoto et al., 2012), whereas they are typically at a steady state in the absence of disturbances (Saiter et al., 2011). High mortality rates, as shown here, may be related to anthropogenic disturbances, as registered in a fragment of semideciduous seasonal forest surrounded by pasture (Silva \& Araújo, 2009), similar to our study area. If we consider fragmentation as a disturbance, high mortality and recruitment rates (and high dynamics) may be related to the deleterious effects of fragmentation itself. Previous studies in SF fragments (Oliveira-Filho et al., 1997; Appolinário et al., 2005; Oliveira-Filho et al., 2007; Higuchi et al., 2008) found disequilibrium in several parameters of tree community dynamics, as pointed out in this study.

Both mortality and recruitment rates estimated here for CE are similar to those of a preserved CE in Mato Grosso (Franczak et al., 2011; Reis et al., 2015), whose tree community is considered hyperdynamic (Marimon et al., 2014). Therefore, the similarity of mortality and recruitment rates between studies suggests that fragmentation can accelerates the dynamics of cerradão vegetation.

\subsection{Edge and interior dynamics and canopy cover}

Edge effects did not influence most parameters of the tree community dynamics in the semideciduous forest and cerradão. Edge effects can be caused by the flows of materials and energy between the matrix and fragment (Paula et al., 2015), affecting the energy flows on microclimatic variables (Didham \& Lawton, 1999), and changing biotic characteristics in the community at broad spatial scales (Laurance et al., 2006; Nascimento \& Laurence, 2006; Aragón et al., 2015).

Forests in several Brazilian and global biomes, including the gallery forests in the Cerrado, are evergreen. While interfluvial forests, such as those of our study, in general are deciduous, whose canopy cover varies throughout the year, and may decrease to less than $50 \%$ in the dry period (Ribeiro \& Walter, 2008). Thus, this canopy cover deciduousness in semideciduous forest and cerradão should promote similar conditions between edge and interior of the fragments throughout the year, and may explain the similarity in the dynamics parameters registered between the edge and the interior of the studied fragments. Therefore, as interfluvial forests are more adapted to stressful conditions, they are also expected to be more resilient to edge effects (Arruda \& Eisenlohr, 2016), contrary to evergreen tropical forests (Camargo \& Kapos, 1995; Guimarães et al., 2008). This climate condition can be related to the predominance of light-demanding and pioneer species, whose physiological adaptations allow them to survive in environments with intense sunlight and low humidity, as occurs in open physiognomies of the Cerrado.

However, despite the remarkable resilience of interfluvial forests, their edges are subject to changes. A previous study in a SF showed subtle edge effects in community parameters (Sampaio \& Scariot, 2011). The authors pointed out that effects of edge were not important, due to species adaptation to harsh environmental conditions and rapid growth in nutrient-rich soils. Indeed, the complexity of edge effects can 
be even greater in the Cerrado than in Amazonian forests, since in the former we have to consider deciduousness and seasonality. Thus, mortality and increase in BA at the edge of the CE may be due to this complexity and linked to natural factors, such as increased light incidence near the edge, which favors pioneer and light-demanding species, that usually have rapid growth and shorter life cycle than shade-tolerant species.

Interfluvial forests are usually less susceptible to edge effects or the interference of the surrounding matrix is less expressive on the fragment (e.g., present study; Oliveira-Filho et al., 1997; Sampaio \& Scariot, 2011; Arruda \& Eisenlohr, 2016). However, the absence, or subtle, edge effects may be partially due to physiological adaptation of species, providing resilience to environmental conditions. In this case, the contact between the forest fragment edge and pasture matrix, as in our study, may increase the environmental heterogeneity of the fragments.

\subsection{Successional stages and edge effects}

Our study represents an important contribution to the understanding of the mechanisms involved in the edge effects of forest fragments, because is one of the few that have addressed this issue with focus to the Cerrado (Lima-Ribeiro 2008; Sampaio \& Scariot, 2011; Arruda \& Eisenlohr, 2016). The tree successional dynamics between physiognomies and between the edge-interior of semideciduous forest and cerradão did not reveal notable differences, even though they are different floristic and structurally. Although, these effects can be long-term evidenced, and requiring future monitoring. However, our results are especially relevant considering that the original Cerrado coverage reduced by almost $80 \%$ until 2010 in the state of Mato Grosso do Sul (IBGE, 2015), and comparative assessments are important for the development of future conservation strategies in Cerrado ecosystems.

\section{CONCLUSIONS}

The SF and CE fragments showed marked forest dynamics, with high mortality and recruitment rates, although the net changes in NI and $\mathrm{AB}$ were not as pronounced in both physiognomies. Therefore, our study indicates that the fragmentation of ecosystems can act as a disturbance agent, causing changes in the dynamics of the Cerrado vegetation.

The dynamics were slightly higher in CE than in SF. SF had a higher NI in the edge, while the CE showed higher mortality (NI) and loss (AB) rates in the edge. There was no difference in abundance and species richness of successional groups between edge and interior. There was seasonal variation in the canopy cover, although we did not found differences between edge and interior. In summary, edge effects in Cerrado forests fragments do not seem to be deleterious on a short-term scale. However, monitoring vegetation is necessary, since especially $\mathrm{CE}$ fragments seems to be more dynamic in the edge.

\section{SUBMISSION STATUS}

Received: 18 Jul. 2020

Accepted: 26 Nov. 2020

Associate editor: Rodrigo Studart Corrêa 10

\section{CORRESPONDENCE TO}

Firmino Cardoso Pereira

Universidade do Estado de Mato Grosso, Campus Nova Xavantina, Rua Prof. Dr. Renato Figueiro Varella, s/n, CEP 78690-000, Nova Xavantina, MT, Brasil

e-mail: firminocpereira@gmail.com

\section{REFERENCES}

APG, Angiosperm Phylogeny Group. An update of the Angiosperm Phylogeny Group classification for the orders and families of flowering plants: APG IV. Botanical Journal of the Linnean Society 2016; 181: 1-20. 10.1111/boj.12385

Appolinário V, Oliveira-Filho AT, Guilherme FAG. Tree population and community dynamics in a Brazilian tropical semideciduous forest. Brazilian Journal of Botany 2005; 28: 347-360. 10.1590/ S0100-84042005000200014

Aragón G, Abuja L, Belinchón R, Martínez I. Edge type determines the intensity of forest edge effect on epiphytic communities. European Journal of Forest Research 2015; 134: 443-451. 10.1007/ s10342-015-0863-5

Arruda DM, Eisenlohr PV. Analyzing the edge effects in a Brazilian seasonally dry tropical forest. Brazilian Journal of Biology 2016; 76: 169-175. 10.1590/1519-6984.16014

Camargo JLC, Kapos V. Complex edge effects on soil moisture and microclimate in central Amazonian forest. Journal of Tropical Ecology 1995; 11: 205-221. 10.1017/S026646740000866X

Christianini AV, Oliveira PS. Edge effects decrease ant-derived benefits to seedlings in a neotropical savanna. Arthropod-Plant Interactions 2013; 7:191-199. 10.1007/s11829-012-9229-9

Didham RK, Lawton JH. Edge structure determines the magnitude of changes in microclimate and vegetation structure in tropical forest fragments. Biotropica 1999; 31: 17-30. 10.1111/j.1744-7429.1999. tb00113.x

Dodonov P, Harper KA, Silva-Matos DM. The role of edge contrast and forest structure in edge influence: vegetation and microclimate at edges in the Brazilian cerrado. Plant Ecology 2013; 214: 1345-1359. 10.1007/s11258-013-0256-0 
Dodonov P, Braga AL, Harper KA, Silva-Matos DM. Edge influence on plant litter biomass in forest and savanna in the Brazilian cerrado. Austral Ecology 2016; 42: 187-197. 10.1111/aec.12420

Franczak DD, Marimon BS, Marimon-Junior BH, Mews HA, Maracahipes L, Oliveira AEA. Changes in the structure of a savanna forest over a six-year period in the Amazon-Cerrado transition, Mato Grosso state, Brazil. Rodriguésia 2011; 62: 425-436. 10.1590/21757860201162215

Guilherme FAG, Nakajima JN. Estrutura da vegetação arbórea de um remanescente ecotonal urbano floresta-savana no Parque do Sabiá, Uberlândia, MG. Revista Árvore 2007; 31: 329-338. 10.1590/ S0100-67622007200016

Guilherme FAG, Oliveira-Filho AT, Appolinário V, Bearzoti E. Effects of flooding regimes and woody bamboos on tree community dynamics in a section of tropical semideciduous forest in southeastern Brazil. Plant Ecology 2004; 174: 19-36. 10.1023/B:VEGE.0000046051.97752.cd

Guilherme FAG, Souza LF, Amaral EVEJ, Coelho CP, Silva GE, Carneiro SES. Flora do Cerrado: ferramentas de conservação da diversidade vegetal no Sudoeste Goiano. Pp:35-52. In: Peixinho DM, Sousa MS (eds). Reconfiguração do Cerrado: usos, conflitos e impactos ambientais. Gráfica UFG; 2016. 268p.

Guimarães JC, Van Den Berg E, Castro GC, Machado EL, Oliveira-Filho AT. Dinâmica do componente arbustivo-arbóreo de uma floresta de galeria aluvial no planalto de Poços de Caldas, MG, Brasil. Revista Brasileira de Botânica 2008; 31: 621-632. 10.1590/ S0100-84042008000400008

Harper KA, Macdonald SE, Burton PK, et al. Edge influence on forest structure and composition in fragmented landscapes. Conservation Biology 2005; 19: 768-82. 10.1111/j.1523-1739.2005.00045.x

Hennenberg, KJ, Goetze, D, Kouamé, L, Orthmann, B, Porembski, $\mathrm{S}$. Border and ecotone detection by vegetation composition along forest-savanna transects in Ivory Coast. Journal of Vegetation Science 2005; 16: 301-310. 10.1111/j.1654-1103.2005.tb02368.x

Higuchi P, Oliveira-Filho AT, Bebber DP, Brown ND, Silva AC, Machado ELM. Spatio-temporal patterns of tree community dynamics in a tropical forest fragment in southeast Brazil. Plant Ecology 2008; 199: 125-135. 10.1007/s11258-008-9418-x

IBGE, Instituto Brasileiro de Geografia e Estatística. Indicadores de desenvolvimento sustentável. Rio de Janeiro, Brasil; 2015.

Ishino MN, De Sibio PR, Rossi MN Edge effect and phenology in Erythroxylum tortuosum (Erythroxylaceae), a typical plant of the Brazilian Cerrado. Brazilian Journal of Biology 2012; 72: 587-594. 10.1590/S1519-69842012000300023

Jardim AVF, Batalha MA. Dispersal syndromes related to edge distance in Cerrado sensu stricto fragments of Central-Western Brazil. Brazilian Archives of Biology and Technology 2009; 52: 1167-1177. 10.1590/S1516-89132009000500014

Laurance WF, Vasconcelos HL. Consequências ecológicas da fragmentação florestal na Amazônia. Oecologia Brasiliensis 2009; 13: 434-451. 10.4257/oeco.2009.1303.030

Laurance WF, Nascimento HEM, Laurance SG, Andrade AC, Fearnside PM, Ribeiro JEL et al. Rain forest fragmentation and the proliferation of sucessional trees. Ecology 2006; 87: 469-482. 10.1890/05-0064
Lewis SL, Phillips OL, Baker TR, Lloyd J, Malhi Y, Almeida S, et al. Concerted changes in tropical forest structure and dynamics: evidence from 50 South American long-term plots. Philosophical Transactions of the Royal Society London Biological Sciences 2004; 359: 421-436. 10.1098/rstb.2003.1431

Lima-Ribeiro MS. Efeitos de borda sobre a vegetação e estruturação populacional em fragmentos de cerradão no Sudoeste Goiano, Brasil. Acta Botanica Brasilica 2008; 22: 535-545. 10.1590/S010233062008000200020

Magrach A, Rodriguez-Perez J, Campbell M, Laurance WF. Edge effects shape the spatial distribution of lianas and epiphytic ferns in Australian tropical rain forest fragments. Applied Vegetation Sciences 2014; 17: 754-764. 10.1111/avsc.12104

Marimon BS, Marimon-Junior BH, Feldpausch TR, OliveiraSantos C, Mews HA, Lopez-Gonzalez G et al. Disequilibrium and hyperdynamic tree turnover at the forest-cerrado transition zone in southern Amazonia. Plant Ecology \& Diversity 2014; 7: 281-292. 10.1080/17550874.2013.818072

Matlack GR. Microenvironment variation within and among forest edge sites in the eastern United States. Biological conservation 1993; 66 (3): 185-194. 10.1016/0006-3207(93)90004-K

Mendonça AH, Russo C, Melo ACG, Durigan G. Edge effects in savanna fragments: a case study in the Cerrado. Plant Ecology \& Diversity 2015; 8: 493-503. 10.1080/17550874.2015.1014068

Miguel A, Marimon BS, Oliveira EA, Maracahipes L, MarimonJunior BH. Dinâmica da comunidade lenhosa de uma floresta de galeria na transição Cerrado-Floresta Amazônica no Leste de Mato Grosso em um período de sete anos (1999 a 2006). Biota Neotropica 2011; 11: 53-61. 10.1590/S1676-06032011000100005

Murcia C. Edge effects in fragmented forests: implications for conservation. Trends in Ecology and Evolution 1995; 10: 58-62. 10.1016/S0169-5347(00)88977-6

Nascimento HEM, Laurance WF. Efeitos de área de borda sobre a estrutura florestal em fragmentos de floresta de terra-firme após 13-17 anos de isolamento. Acta Amazonica 2006; 36: 183-192. 10.1590/S0044-59672006000200008.

Oliveira AP, Schiavini I, Vales VS. Mortality, recruitment and growth of the tree communities in three forest formations at the Panga Ecological Station over ten years (1997-2007). Acta Botanica Brasilica 2014; 28: 234-248. 10.1590/S0102-33062014000200010

Oliveira-Filho AT, Carvalho WAC, Machado ELM, Higuchi P, Appolinário V, Castro GC et al. Dinâmica da comunidade e populações arbóreas da borda e interior de um remanescente florestal na Serra da Mantiqueira, Minas Gerais, em um intervalo de cinco anos (1999-2004). Revista Brasileira de Botânica 2007; 30: 149-161. 10.1590/S0100-84042007000100015

Oliveira-Filho AT, Mello JM, Scolforo JRS. Effects of past disturbance and edges on tree community structure and dynamics within a fragment of tropical semideciduous forest in south-eastern Brazil over a five-year period (1987-1992). Plant Ecology 1997; 131: 45-66. 10.1023/A:1009744207641

Paula MD, Groeneveld J, Huth A. Tropical forest degradation and recovery in fragmented landscapes: simulating changes in tree community, forest hydrology and carbon balance. Global Ecology and Conservation 2015; 3: 664-677. 10.1016/j.gecco.2015.03.004 
Peixoto KS, Sanchez M, Pedroni F, Ribeiro MN, Facure KG, Gomes-Klein VL, Guilherme FAG. Dinâmica da comunidade arbórea em uma Floresta Estacional Semidecidual sob queimadas recorrentes. Acta Botanica Brasilica 2012; 26: 697-708. 10.1590/ S0102-33062012000300020

Phillips OL, Baker TR, Arroyo L, Higuchi N, Killeen TJ, Laurance WF at el. Pattern and process in Amazon tree turnover, 1976-2001. Philosophical Transactions of the Royal Society B: Biogical Science 2004; 359: 381-407. 10.1098/rstb.2003.1438

Porensky, LM. When edges meet: interacting edge effects in an African savanna. Journal of Ecology 2011; 99: 923-934. 10.1111/j.1365-2745.2011.01824.x

Reis, SM, Lenza, E, Marimon, BS, Gomes, L, Forsthofer, M, Morandi, OS, Marimon Junior, BH, Feldpausch, TR, Elias, F. Post-fire dynamics of the woody vegetation of a savanna forest (Cerradão) in the Cerrado-Amazon transition zone. Acta Botanica Brasilica 2015; 29: 408-416. 10.1590/0102-33062015abb0009

Ribeiro JF, Walter BMT. As principais fitofisionomias do Bioma Cerrado. In: Sano SM, Almeida SP, Ribeiro JF (eds). Cerrado: ecologia e flora. Brasília: Embrapa; 2008.

Saiter FZ, Guilherme FAG, Thomaz LD, Wendt T. Tree changes in a mature rainforest with high diversity and endemism on the Brazilian coast. Biodiversity and Conservation 2011; 20: 1921-1949. 10.1007/s10531-011-0067-3

Sampaio AB, Scariot A. Efeito de borda na diversidade, composição e estrutura da comunidade arbórea em uma Floresta Estacional Decidual no Brasil Central. Revista Árvore 2011; 35: 1121-1134. 10.1590/S0100-67622011000600018

Sheil D, Jennings S, Savill P. Long-term permanent plot observations of vegetation dynamics in Budongo, a Ugandan rain forest. Journal of Tropical Ecology 2000; 16: 765-800. 10.1017/S0266467400001723
Silva MR, Araújo GM. Dinâmica da comunidade arbórea de uma floresta semidecidual em Uberlândia, MG, Brasil. Acta Botanica Brasilica 2009; 23: 49-56. 10.1590/S0102-33062009000100006

Smit IPJ, Asner GP. Roads increase woody cover under varying geological, rainfall and fire regimes in African savanna. Journal of Arid Environments 2012; 80: 74-80. 10.1016/j.jaridenv.2011.11.026

Swaine, MD, Whitmore, TC On the definition of ecological groups in tropical rainforest. Vegetatio 1988; 75: 81-86. 10.1007/BF00044629

Terra MCNS, Teodoro GS, Pifano DS, Fernandes FB, Silva TMC, Berg EVD. Tree responses to soil and edge effects in a semideciduous forest remnant. Floresta e Ambiente 2018; 25: e20160542. 10.1590/21798087.054216

Vogado NO, Camargo MGG, Locosselli GM, Morellato LPC. Edge effects on the phenology of the guamirim, Myrcia guianensis (Myrtaceae), a cerrado tree, Brazil. Tropical Conservation Science 2016; 9: 291-312. 10.1177/194008291600900115

Wachholz F, Rocha IR, Souza RO, Cabral JBP. Avaliação do meio físico de uma área de interesse de Mata Atlântica no sul de Goiás. Geoambiente Online 2020; 36:163-185.

Zar JH. Bio statistical Analysis, New Jersey, Prentice Hall; 2010.

\section{SUPPLEMENTARY MATERIAL}

The following online material is available for this article: Supplementary S1 - Field data fragments of semidecidual forests (SF) and cerradão (CE) in Cassilândia, Mato Grosso do Sul. Supplementary S2 - Dynamics Rates.

Supplementary S3 - List of species and successional stages (SS) of fragments of semidecidual forests (SF) and cerradão in Cassilândia, Mato Grosso do Sul, central Brazil. 